\title{
EFISIENSI PENGGUNAAN IMUNOSTIMULAN DALAM PAKAN TERHADAP LAJU PERTUMBUHAN, RESPON IMUN DAN KELULUSHIDUPAN UDANG VANNAMEI (Litopenaeus vannamei)
}

\author{
Ken Darwantin ${ }^{*}{ }^{1}$, Romziah Sidik ${ }^{2}$ dan Gunanti Mahasri ${ }^{3}$ \\ ${ }^{1}$ Program Studi S2 Bioteknologi Perikanan dan Kelautan, Universitas Airlangga, Surabaya \\ ${ }^{2}$ Fakultas Farmasi, Universitas Airlangga, Surabaya \\ ${ }^{3}$ Fakultas Perikanan dan Kelautan, Universitas Airlangga, Surabaya \\ e-mail: *bayureta21@gmail.com, ${ }^{2}$ mahasritot@gmail.com
}

\begin{abstract}
Abstrak
Pemberian Pakan buatan berimunostimulan dari protein membran imunogenik Zoothamnium penaei merupakan salah satu upaya pencegahan penyakit pada udang vaname (Litopenaeus vannamei), karena penggunaan antibiotik maupun bahan kimia lain belum memenuhi target. Tujuan dari penelitian ini adalah mengetahui efektifitas penggunaan imunostimulan dalam pakan terhadap laju pertumbuhan, peningkatkan respon imun dan kelulushidupan udang vaname. Metode penelitian dari penelitian ini adalah eksperimen laboratorik dengan pemberian pakan buatan berimunostimulan dari protein membran imunogenik Zoothamnium penaei dengan dosis 10\%. Hasil penelitian menunjukkan bahwa pakan berimunostimulan dapat meningkatkan respons imun dan kelulushidupan udang vaname tetapi tidak memberikan pengaruh terhadap laju pertumbuhan. Total Haemocyte Count (THC) dan Diferrensial Haemocyte Cout (DHC) sama-sama tertinggi terjadi pada udang vaname yang diberi pakan buatan berimunostimulan dengan dosis $10 \%$ yaitu sebesar 59,3000 sel/ml dan 14,4875\% dengan kelulushidupan tertinggi sebesar 37,50\% serta laju pertumbuhan sebesar 0,2108. Pemberian pakan buatan berimunostimulan dengan dosis $10 \%$ memberikan pengaruh yang nyata dan merupakan dosis optimum untuk meningkatkan respon imun dan kelulushidupan, walaupun tidak dapat meningkatkan laju pertumbuhan udang.
\end{abstract}

Kata kunci: Udang vaname (Lithopenaeus vannamei), Imunostimulan, Respon imun (THC, DHC), Kelulushidupan, Laju Pertumbuhan

\begin{abstract}
Feed artificial with immunostimulant from immunogenic membrane protein of Zoothamnium penaei is one preventive methode is one of diseases prevented on white shrimp (Litopenaeus vannamei), because to controle the diseases by using antibyotic and other chemically just not success until now. The general porpuse of this research is want to know the effectifity of feed with immunostimulant for growth rate, respons immun and survival rate on white shrimp. This researchwas designed by using experimental laboratory methods which used completed random sampling (4x5) to application of artificial feed with immunostimulant for increase the growth rate, immun respons and survival rate of white shrimp. The result showed that the highest of the Total Haemocyte Count (THC) and Diferrensial Haemocyte Cout (DHC both are happened on white shrimp were given artificial feed with immunostimulant $10 \%$ are $59,300 \mathrm{sel} / \mathrm{ml}$ and $14,4875 \%$ and the survival rate are 0,2108. So that thisi feed atificial with immunostimulant $10 \%$ is optimum dosis for increase immun respons and survival rate, although can not increase the groeth rate of white shrimp.
\end{abstract}

Keywords: White Shrimp (Lithopenaeus vannamei),Immunostimulant,Immun Respons (THC, DHC), Survival Rate, Growth Rate

JBP Vol. 18, No. 2, Agustus 2016-Ken Darwantin 


\section{PENDAHULUAN}

Udang vanamei (Litopenaeus vannamei) masuk ke Indonesia pada tahun 2001 dan dikeluarkannya izin dari pemerintah tahun 2002 untuk impor induk udang vanamei, usaha budidaya ini berkembang pesat, hingga tahun 2007 Indonesia mampu mengekspor 125.598 ton udang vanamei. Produksi udang vannamei di Indonesia selalu mengalami peningkatan dari tahun sejak tahun 2012 sampai tahun 2015, berturut-turt sebesar 778.976, 923.568, 1.112.349 dan 1.734.236 ton (KKP, 2016). Udang vannamei mempunyai beberapa keunggulan yang dimiliki antara lain adalah responsif terhadap pakan, tahan serangan penyakit serta adaptif di lingkungan menjadi daya tarik tersendiri bagi para petambak udang.

Banyak kendala yang perlu diwasdai pada budidaya udang vanamei di tambak, dimana kendala utama yang masih sulit dikendalikan antara lain adalah penyediaan pakan dan air media pemeliharaan yang berkualitas dan adanya serangan penyakit. Pakan menyerap 60\%-70\% dari biaya operasional budidaya udang, sehingga efisiensi dari pakan tersebut perlu dipertimbangkan oleh petambak. Nilai nutrisi dari pakan akan mempengaruhi pertumbuhan udang, misalnya protein, lemak, karbohidrat, vitamin dan mineral. Udang tidak dapat mensintesis protein dan asam amino secara alami, oleh sebab itu asupan protein dari pakan buatan sangat penting untuk pertumbuhan udang (Nuhman, 2009). Pakan yang baik adalah pakan yang mengandung nutrisi lengkap, tidak rusak maupun berjamur. Penggunaan pakan komersil harus memperhatikan kandungan gizi pakan, dengan kadar protein minimal 30\% (WWF Indonesia, 2014).

Efisiensi penggunaan pakan ditentukan oleh kemampuan udang untuk mencerna dan sisa pakannya berjumlah sedikit, untuk itu strategi pemberian pakan selain penggunaan pakan yang memiliki kualitas tinggi, terjangkau harganya juga harus sesuai dengan kebutuhan kultivan. Formulasi pakan yang lengkap menyangkut, susunan nutrisi yang lengkap, bahan baku berkualitas baik dan mengandung profil nutrien sesuai kebutuhan kultivan yang juga perlu mendapat perhatian (Herawati, 2005).

Pakan yang diberikan pada udang berperan dalam peningkatan kualitas dan pertumbuhan udang. Penambahan bobot pada udang dan laju pertumbuhan dipengaruhi oleh penyerapan nutrisi yang terkandung pada pakan (Suwoyo dan Mangampa, 2010). Pakan uji dengan kandungan 48,49\% protein, $12,46 \%$ karbohidrat dan $19,15 \%$ lemak yang ditambah dengan bahanbahan imunostimulan (ragi komersial, vitamin $\mathrm{C}$, $\beta$-glukan dan kromium yeast) terbukti mampu memberikan pengaruh yang sama dengan pakan komersil terhadap laju pertumbuhan ikan kebaru bebek sebesar 1,50\%-1,69\% per hari yang berarti nutrisi pakan uji bias memenuhi kebutuhan dasar dan pertumbuhan ikan (Suprayudi, dkk., 2006).

Beragam penelitian mengenai pakan buatan yang tepat untuk usaha budidaya dan upaya penambahan feed additive pada pakan guna mendukung optimalisasi penyerapan pakan dan peningkatan kualitas kesehatan udang telah banyak dilakukan. Menurut Amrina, dkk. (2013) pemberian pakan buatan $10 \%$ silase ikan Gabus terbukti berpengaruh pada pertumbuhan mutlak sebab mampu memberikan asupan protein yang cukup untuk pertumbuhan udang. Hal ini disebabkan semakin banyak protein yang disimpan dalam tubuh dan semakin sedikit yang dikatabolisme menjadi energi maka nilai pertumbuhan akan semakin besar (Heptarina, dkk., 2010).

Penyakit merupakan kendala utama yang perlu mendapat perhatian selain pakan. Hal ini disebabkan serangan penyakit umumnya secara mendadak dan dapat meyebabkan kematian udang. Penyakit dapat disebabkan oleh serangan bakteri, virus, jamur maupun parasit. Penyakit yang disebabkan oleh The Necrotizing Hepatopancreatitis Bacterium (NHPB) misalnya dapat menyebabkan menurunnya konsumsi pakan pada udang, melunaknya cangkang udang, jaringan otot menjadi lembek, insang berwarna gelap dan penyusutan pada organ hepatopankreas. Sementara penyakit yang disebabkan oleh Infectious Myonecrosis Virus (IMNV) dapat menyebabkan kematian udang $40 \%$ hingga $70 \%$ menjelang panen (Loy, 2011)

Permasalahan terkait dengan kemunculan penyakit seringkali menimbulkan kerugian yang signifikan pada populasi udang. Selain itu juga menimbulkan kerugian ekonomi yang besar dalam usaha budidaya udang secara komersial. Salah satu penyakit yang sering menyerang udang vanamei di tambak dan panti pembenihan adalah zoothamniosis (Departemen Kelautan RI , 2005) yaitu penyakit parasiter pada udang yang disebabkan oleh serangan Zoothamnium penaei dari ciliata. 
Upaya pencegahan penyakit terutama zoothamniosis pada udang windu dengan immunostimulan protein membran immunogenik Zoothamnium penaei sudah dilakukan oleh Mahasri (2007), hasil yang dilaporkan menunjukkan bahwa immunostimulan tersebut dapat meningkatkan pertahanan tubuh udang windu dan dapat meningkatkan kelangsungan hidup udang windu hingga $86 \%$. Kemudian Harijanto (2011) juga sudah melakukan penelitian bahwa penggunaan imunostimulan dari protein membrane Zoothamnium penaei yang diberikan secara perendaman (dipping) dapat meningkatkan kelulushidupan udang vaname dari 26\% hingga $83 \%$. Aplikasi imunostimulan dari protein tersebut juga sudah dilakukan di tambak pada udang windu yang dapat meningkatkan kelulushidupan udang windu dari 16\% menjadi 78\% (Gustrifandi, 2013), sementara pada udang vanamei kelulushidupan meningkat dari 10\% hingga 84\% (Mahasri, 2013).

Berdasarkan latar belakang di atas maka aplikasi pakan dengan penambahan imunostimulan dari protein membran imunogenik Zoothamnium penaei bertujuan untuk meningkatkan laju pertumbuhan, ketahanan tubuh dan kelulushidupan udang vaname.

\section{TINJAUAN PUSTAKA}

\subsection{Udang Vanamei}

\subsubsection{Klasifikasi dan morfologi}

Menurut Pérez-Farfante dan Kensley

(1997) taksonomi udang vanamei adalah sebagai berikut:

$\begin{array}{lc}\text { Kingdom } & \text { : Animalia } \\ \text { Phylum } & \text { : Arthropoda } \\ \text { Class } & : \text { Malacostraca } \\ \text { Ordo } & \text { : Decapoda } \\ \text { Family } & : \text { Penaeidae } \\ \text { Genus } & : \text { Litopenaeus } \\ \text { Species } & : \text { Litopenaeus vannamei }\end{array}$

Menurut Zakaria (2010) tubuh udang vanamei terbagi menjadi cephalothorax yang merupakan penyatuan kepala dan dada, abdomen (perut) dan uropod (ekor). Cephalothorax udang ditutupi cangkang berujung runcing dan bergigi (rostrum), terdapat juga sepasang antennulae dan antenna. Udang juga memiliki tiga pasang maxiliped yang telah mengalami modifikasi dan berfungsi sebagai organ makan (Haliman dan Adijaya, 2005).

Udang vanamei jantan dibedakan dari betina melalui alat kelamin luarnya. Pada jantan alat kelamin disebut petasma dan terletak di dekat kaki renang pertama sementara lubang saluran kelamin ada di antara pangkal kaki jalan keempat dan kelima (Zakaria, 2010). Udang vanamei mengalami molting secara periodik, seluruh tubuhnya tertutup oleh eksoskeleton dari kitin. Terdapat pigmen keratenoid pada kulit udang yang semakin berkurang seiring pertumbuhan udang, sebab ketika molting sebagian pigmen akan terbuang (Haliman dan Adijaya, 2005)

\subsection{2. $\quad$ Sifat - sifat udang}

Sifat-sifat penting udang vanamei (Litopenaeus vannamei) menurut Haliman dan Adijaya (2005) adalah : a) Aktif pada kondisi gelap (nocturnal), b) Suka memangsa sesama jenis (kanibal), c) Tipe pemakan lambat, tetapi terus menerus ( continous feeder), d) Menyukai hidup di dasar (bentik), e) Mencari makan lewat sensor (hemoreceptor) dan f) Dapat hidup pada kisaran salinitas lebar (euryhalyne).

\subsubsection{Penyebaran dan habitat}

Udang vanamei (Litopenaus vanamei) merupakan udang asli dari Pantai Pasifik Barat Amerika Latin, diperkenalkan di Tahiti pada awal tahun 1970 untuk penelitian potensi wilayah. Kemudian pengembangan budidaya yang intensif di Hawaii, utara - barat pantai Pasifik, pantai timur Atlantik (South Carolina), Teluk Meksiko (Texas), Belize, Nikaragua, Kolombia, Venezuela, dan Brazil di akhir tahun 1970-an dan sebelum 1980. Udang vanamei diperkenalkan di Asia untuk tujuan penelitian pada tahun 1978 - 1979 dan baru dikembangkan secara komersial pada tahun 1996 di Cina daratan, Taiwan, Vietnam, Thailand, India dan Philipina (Briggs et al. 2004).

Udang putih masuk ke Indonesia pada tahun 2001 dan pada bulan Mei 2002, pemerintah memberikan ijin kepada dua perusahaan swasta yang mengimpor induk udang putih sebanyak 2.000 ekor, 5.000.000 benur dari Hawai dan Taiwan serta 300.000 benur dari Amerika Latin. Induk dan benur tersebut kemudian dikembangkan oleh para pengusaha hatchery pemula dan sekarang usaha tersebut telah dikomersilkan dan berkembang cukup pesat (Briggs dkk, 2006), menyatakan bahwa udang vanamei hidup di habitat laut tropis dimana suhu air biasanya lebih dari $20^{\circ} \mathrm{C}$ sepanjang tahun. Udang vanamei dewasa dan bertelur di laut terbuka, sedangkan pada stadia post larva udang vanamei akan bermigrasi ke pantai sampai pada stadia juvenil (DKP, 2005).

Penelitian yang dilakukan di Laguna Mar Muerto, Meksiko menunjukkan bahwa udang vaname banyak ditemukan di wilayah laguna dengan kedalaman kurang dari 1 mater dan substrat 
dasar berupa lumpur. Udang fase juvenil jumlahnya menurun selama periode sampling bulan Februari dan jumlahnya naik ketika bulan Maret hingga Mei yang merupakan akhir musim kemarau dan memasuki musim penghujan ( Reyna, 2001)

Menurut Kordi (2007), udang vanamei yang berasal dari Hawai kini telah banyak dikembangkan di Taiwan, Cina, Thailand dan Vietnam. Sedangkan di Indonesia, udang vanamei telah dibudidayakan di Lampung, Jawa Timur dan Sulawesi Selatan (Kabupaten Mamuju, Bulukumba dan Barru).

\subsection{Pakan, nutrisi dan kebiasaan makan}

Haliman dan Adijaya (2005) menyatakan pemberian pakan sebaiknya merata, satu individu udang dapat memperoleh bagian pakan yang sama dengan individu yang lainnya. Pemberian pakan yang merata menghindari terjadinya kompetisi dalam mendapatkan makanan. Apabila kompetisi dapat dihindari maka kanibalisme dapat dihindarkan. Syarat-syarat pakan udang yang baik antara lain : a) Kondisi fisik permukaan rata, b) Berbau amis segar, kering dan tidak apek, c) Kemasan pakan tidak rusak, d) Water stability pellet yang bagus apabila dapat bertahan pada air setidaknya 2 - 3 jam, e) Ukuran pellet yang benar sesuai ukuran kemampuan makan udang dan bukaan mulut udang, f) Bahan baku tepung ikan segar ketika dikunyah berasa manis dan g) Attractability pakan berkualitas bagus sehingga pakan akan lebih cepat dikonsumsi udang.

Kualitas pakan yang baik tergantung pada kandungan protein, lemak, serat kasat dan beberapa nutrien lain yang perlukan bagi pertumbuhan udang. Menurut Heptarina, dkk. (2010) pakan dengan kadar protein 35\%, 15,20\% lemak dan $5,31 \%$ serat kasar menghasilkan pertumbuhan yuwana udang vanamei dan konversi pakan terbaik. Selain kadar protein yang sesuai, kadar lemak yang tidak terlalu tinggi membuat udang mengkonsumsi pakan yang cukup untuk pertumbuhannya. Pada perlakukan lain di mana kadar lemak mencapai 17,36\%, konsumsi pakan menjadi rendah sebab pada batas jumlah tertentu udang akan menghentikan aktivitas makannya akibat energi yang terlalu tingggi pada pakan dan nutrien pakan yang lain seperti protein akan kecil kemungkinannya untuk masuk ke tubuh udang sehingga laju pertumbuhan menjadi rendah. Nutrisi pada pakan seperti protein, lemak, karbohidrat, mineral dan vitamin menjadi faktor penting yang mendukung kelangsungan hidup dan laju pertumbuhan pada udang.

\subsubsection{Protein}

Udang vanamei membutuhkan kandungan protein $35 \%$ pada pakan (Subaidah, dkk., 2010). Menurut penelitian yang dilakukan Heptarina, dkk (2010) protein yang semakin tinggi pada pakan berdampak pada peningkatan retensi protein dalam tubuh. Penelitian yang dilakukan terhadap udang vanamei yang diberi pakan dengan konsentrasi protein berbeda menunjukkan hasil yang signifikan, kadar protein sebesar $29 \%$ pada pakan memiliki nilai retensi protein dalam tubuh sebesar $11,5 \%$ dan kadar protein $40 \%$ pada pakan memiliki nilai retensi protein sebesar $36,4 \%$ dalam tubuh udang. Makin tinggi kecernaan protein dan makin rendah ammonia yang terbuang menunjukkan bahwa makin besar protein yang dimanfaatkan udang untuk pertumbuhan. Sumber protein lain yang mulai diteliti adalah tepung usus ayam, sebab pakan merupakan komponen pembiayaan terbesar dan perlu bahan alternatif yang dapat mensubtitusi tepung ikan. Menurut hasil penelitian Yusniati, dkk (2013) komposisi $40 \%$ tepung ikan dan $60 \%$ tepung usus ayam dapat memberi pengaruh pada kelangsungan hidup hingga 93,33\%. Sementara komposisi $60 \%$ tepung ikan dan $40 \%$ tepung usus ayam merupakan kombinasi yang baik untuk pertumbuhan udang vanamei.

\subsubsection{Lemak}

Lemak ditambahkan pada pakan buatan untuk peningkatan nilai gizi dan juga sumber energi bagi pakan serta menjaga agar pakan tidak pecah. Lemak mempengaruhi berfungsinya hormon, melindungi jaringan syaraf, membantu permeabilitas selaput sel, membantu penyerapan mineral serta vitamin yang terlarut dalam lemak, membantu proses metabolisme dan menjaga keseimbangan daya apung ikan di air (Herawati, 2005).

\subsubsection{Karbohidrat}

Karbohidrat merupakan zat sumber energi yang berasal dari tumbuhan yang proses pembentukannya melalui fotosintesis. Daya cerna terhadap karbohidrat akan mempengaruhi pemanfaatan karobohidrat oleh tubuh (Herawati, 2005). Menurut Sutiyono (1998), diperlukan kandungan karbohidrat sekitar $40 \%$ untuk pertumbuhan udang, khususnya udang windu.

\subsubsection{Mineral}

Sukarman dan Lili Sholichah (2011) menyatakan bahwa mineral dalam tubuh hewan berperan dalam menjaga proses metabolisme, menjaga keseimbangan tekanan osmotik, bahan 
pembentuk tulang dan karapaks, sebagai ko enzim serta penyeimbang asam dan basa dalam tubuh. Meski terdapat juga dalam air, namun kandungan mineral kadang tidaklah stabil sehingga diperlukan penambahan mineral untuk mencukupi kebutuhan bagi pertumbuhan organisme. Mineral digolongkan menjadi dua, yakni mineral makro dan mineral mikro. Contoh mineral makro seperti, kalsium, fosfor, magnesium, sodium, klor dan potasium.

Kalsium penting untuk pertumbuhan karapaks pada krustase dan diserap oleh tubuh melalui insang. Kalsium didapat dari bahan baku tepung ikan. Sementara fosfor berperan dalam pembentukan nukleotida serta membran sel. Ketersediaan fosfor dalam air sangat rendah sehingga harus ditambahakan dalam pakan udang. Mineral mikro yang juga diperlukan bagi pertumbuhan udang adalah, besi $(\mathrm{Fe})$, copper $(\mathrm{Cu})$, seng (Zn), iodium (I), dan lain-lain. Udang mendapatkan mineral dari air sebagai media hidupnya dan juga dari makanan. Baik mineral dalam pakan maupun dari air memiliki variasi yang sangat tinggi, oleh sebab itu perlu adanya suplementasi mineral murni dalam pakan, yang kadarnya harus diperhatikan agar tidak menjadi toksik bagi udang.

\subsubsection{Vitamin}

Kandungan protein dan lemak yang dominan pada pakan, membuat kebutuhan mineral dan vitamin menjadi terlupakan (Sukarman dan Sholichah, 2011) padahal elemen ini juga tak kalah penting dalam proses metabolisme. Berdasarkan penelitian Pamungkas, dkk. (2007) dibuktikan bahwa kenaikan Indeks Gonado Somatik (IGS) sejalan dengan kenaikan kadar vitamin $\mathrm{C}$, kandungan vitamin $\mathrm{C}$ dalam ovarium meningkat seiring bertambahnya kandungan vitamin $\mathrm{C}$ pada pakan. Pada penambahan $0,10 \%$ vitamin $\mathrm{C}$ pakan, terdapat $282 \mu \mathrm{g} / \mathrm{g}$ vitamin $\mathrm{C}$ pada ovarium, sementara pakan tanpa penambahan hanya memiliki $132 \mu \mathrm{g} / \mathrm{g}$ vitamin $\mathrm{C}$ di ovarium induk udang. Hal ini berarti suplementasi vitamin $\mathrm{C}$ berpengaruh nyata terhadap perkembangan gonad induk udang.

Frekuensi pemberian pakan pada udang berumur kurang dari satu bulan, cukup 2-3 kali sehari, karena pakan alami masih cukup tersedia di tambak. Setelah udang berumur 30 hari maka frekuensi pemberian pakan ditingkatkan menjadi 4-5 kali sehari dengan panduan anco untuk menentukan jumlah pakan. Kelebihan jumlah pakan yang ditebar bisa memperburuk kualitas air serta menyebabkan konsentrasi amoniak dan nitrit yang kurang baik untuk pertumbuhan udang serta kadar oksigen yang menurun akibat penguraian bahan organik (WWF Indonesia, 2014).

Haliman dan Adijaya (2005)

menambahkan, setiap pemberian pakan, $2 \%-4 \%$ dari jumlah total pakan yang ditebar harus dimasukkan ke anco. Hal ini merupakan tindakan kontrol terhadap aktifitas memakan udang. Dua jam kemudian, anco dapat diangkat dan diperiksa sisa pakan yang ada dengan demikian dapat diprediksi kebutuhan pakan udang.

Di tambak alami, alga dan bakteri yang berkembang pada air merupakan sumber nutrisi yang penting bagi udang vanamei serta mampu meningkatkan pertumbuhan sebesar $50 \%$ dibanding tambak yang jernih sebab udang tumbuh optimum pada tambak yang berimbang dengan komunitas mikroba. Udang vanamei membutuhkan pakan dengan 35\% kandungan protein, lebih rendah dari yang dibutuhkan Penaeus monodon dan Penaeus japonicus. Pakan dengan kandungan protein tinggi (45\%) dapat mempercepat pertumbuhan udang, demikian juga dengan pakan yang mengandung ikan dan cumi-cumi mampu meningkatkan laju pertumbuhan (Subaidah,dkk. 2010).

Penggunaan feed additive sebagai pemicu perumbuhan alami saat ini mendapat perhatian dalam industri perikanan. Di samping itu, penggunaan antibiotik, antioksidan, feed stimulan, pewarna pakan, dan penggunaan hormon tertentu mulai dilakukan oleh beberapa peneliti (Ajiboye et.al., 2012). Jika ingin memberikan feed additive untuk membantu meningkatkan penyerapan nutrisi dan daya tahan (immunostimulan) maka pemberian bisa dilakukan setiap hari bersamaan dengan pemberian pakan, dan sebaiknya saat nafsu makan paling tinggi yakni pada siang hari (WWF Indonesia, 2014). Penggunaan feed additive haruslah bahan yang ramah lingkungan dan mampu memberikan peningkatan kualitas kesehatan pada udang, misalnya peningkatan sistem imun. Penggunaan Herbal Feed Additive (HFA) pada Penaeus semisulcatus terbukti dapat meningkatkan aktivitas PO. Berdasarkan hasil percobaan, aktivitas PO memiliki nilai paling tinggi pada pakan yang memiliki kandungan $1 \%$ HFA (107.80 \pm 5.62$)$ lalu diikuti dengan pakan yang mengandung $2 \% \quad$ HFA $\quad(71.44 \pm 4.80)$ lalu

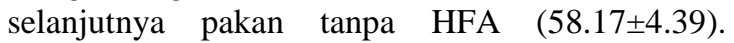
Peningkatan aktivitas PO menunjukkan kemampuan HFA untuk menginduksi respon imun non spesifik pada udang (Al-Musalam, et.al, 2014).

Selain HFA, probiotik juga memberikan pengaruh yang baik untuk pertumbuhan udang. Berdasarkan penelitian yang dilakukan Fauzi, dkk (2015) probiotik berpengaruh terhadap penambahan bobot udang karena adanya 
pengontrolan keseimbangan mikroba dalam saluran cerna, peningkatan penyerapan nutrien dan perbaikan nilai nutrisi pakan.

\subsection{Konsumsi pakan}

Konsumsi pakan pada ikan merupakan seberapa banyak pakan yang diperlukan ikan dalam sehari-hari (rutinitas sehari-hari). Avrianto dan Liviawati (2005) menyatakan bahwa pakan merupakan sumber energi bagi ikan untuk bergerak, metabolisme dan pertumbuhan. Konsumsi pakan tersebut dipengaruhi oleh beberapa faktor antara lain bentuk, lingkungan dan spesies ikan. Disamping itu juga faktor penyebaran organisme sebagai pakan ikan, ketersediaan pakan jenis yang sesuai atau pilihan ikan dan faktor fisik lingkungan juga mempengaruhi ikan dalam mengkonsumsi pakan (Effendi, 2002).

Menurut Yustianti, dkk menyatakan bahwa nutrisi pakan udang vannamei harus menggunakan komposisi protein yang tinggi, yaitu lebih dari $30 \%$. Secara lengkap komposisi pakan udang yang dapat meningkatkan kelulushidupan dan laju pertumbuhan yang optimal adalah : Protein sebesar 47.51\%, Lemak 13.11, Kadar air 9.17\%, Serat Kasar 2,32\%, Kadar abu $12.40 \%$ dan BETN $15.46 \%$

\subsection{Pertumbuhan ikan}

Pertumbuhan merupakan pertambahan ukuran tulang, otot, organ internal dan bagian tubuh yang lain (Einsminger, et al., 1990) Selanjutnya dikatakan bahwa pertumbuhan juga dapat diartikan sebagai pertambahan ukuran panjang dan atau berat ikan pada waktu tertentu (Effendi, 2002). Kemudian dalam suatu populasi pertumbuhan didefinisikan sebagai pertambahan jumlah individu. Menurut Boeuf and Payan (2001) menyatakan bahwa banyak faktor yang mempengaruhi pertumbuhan dan perkembangan ikan yang dapat dibagi menjadi factor internal dan ekternal. Selanjutnya dikatakan bahwa factor internal dapat berupa saraf, kelenjar endokrin, neuroendokrin dan faktor eksternal meliputi lingkungan yang berupa faktor fisika, misalnya kedalaman dan warna. Faktor kimia antara lain oksigen, karbon dioksida, amoniak, serta faktor biologi yang dapat berupa plankton yang berada di perairan. Faktor lingkungan terutama suhu dan salinitas sering berfluktuasi bersamaan sehingga dapat mempengaruhi konversi pakan dan asupan pakan pada ikan, dimana $20-50 \%$ energi total yang dimiliki ikan digunakan dalam proses osmoregulasi (Boeuf dan Payan, 2001).
Pertumbuhan pada ikan dibagi memnjadi pertumbuhan panjang mutlak yaitu hasil dari selisih panjang tubuh ikan pada akhir pemeliharaan dengan panjang tubuh ikan pada awal pemeliharaan. Sedangkan laju pertumbuhan yaitu merupakan pertambahan bobot tubuh yang dihasilkan selama waktu tertentu yang diukur dalam persen. Laju pertumbuhan akan menurun dengan bertambahnya umur ikan.

\subsection{Peran pakan dalam kelangsungan hidup dan laju pertumbuhan}

Pakan merupakan salah satu faktor pembatas yang selain berpengaruh pada biaya produksi juga mempengaruhi kelangsungan hidup dan laju pertumbuhan udang. Menurut penelitian yang dilakukan Panjaitan, dkk (2014) pakan buatan yang diberikan pada larva udang vaname justru menghasilkan sintasan 0\% karena pakan sulit dimangsa dan tidak sesuai dengan bukaan mulut larva. Sementara kelompok larva yang diberi pakan campuran fitoplankton Thalassiosira weissflogii dan Chaetoceros calcitrans menghasilkan sintasan $77,04 \%$ hal ini disebabkan nilai nutrisi dari kombinasi ini mampu mencukupi kebutuhan nutrisi larva dibanding penggunaan salah satu jenis fitoplankton saja. Faktor pertumbuhan sangat memberikan pengaruh pada jumlah konsumsi pakan. Udang yang lebih besar memerlukan asupan pakan yang lebih besar. Jumlah konsumsi pakan rendah sebanding dengan nilai pertumbuhan yang rendah, hal ini terjadi pada udang yang lebih kecil yang mengkonsumsi pakan dengan jumlah yang lebih sedikit (Heptarina, dkk., 2010).

Efisiensi pakan menjadi aspek lain yang dipertimbangkan dalam usaha budidaya. Penggunaan bioflok misalnya, dinilai mampu menurunkan rasio konversi pakan sebab peran bakteri heterotrof non patogen yang dapat menghasilkan enzim ekstraseluler meningkatkan kecernaan bahan makanan dalam usus udang sehingga mudah diserap tubuh. Nilai rasio konversi pakan yang rendah mengindikasikan semakin efisien udang dalam memanfaatkan pakan yang dikonsumsi (Riani, dkk., 2012) sehingga berdampak pada efesiensi biaya produksi pengadaan pakan udang.

Menurut Nuhman (2009), persentase pemberian pakan pada udang sebesar $20-50 \%$ dari berat biomassa / hari merupakan takaran ideal untuk laju pertumbuhan dan kelangsungan hidup udang. Perbedaan persentase pemberian pakan memberikan pengaruh nyata pada laju pertumbuhan udang, dengan takaran optimal $40 \%$ dari berat biomassa / hari, memberikan laju 
pertumbuhan tertinggi yaitu 9,86\%. Perlakuan pada udang windu yang diberi pakan $50 \%$ dari bobot biomassa dan penambahan probiotik pada media hidupnya menghasilkan nilai sintasan hingga 60,33\% (Muliani, dkk., 2010).

\subsection{Peningkatan kualitas pakan}

Selain sebagai pemasok nutrien, pakan juga memiliki peran meningkatkan kualitas kesehatan udang dan juga ketahanannya terhadap penyakit. Banyak upaya dilakukan untuk meningkatkan kualitas pakan seperti penambahan probiotik, immunostimulan maupun pemacu pertumbuhan udang. Penambahan probiotik melalui pakan misalnya, menurut Widanarni, dkk (2012) berdampak signifikan terhadap laju pertumbuhan hingga 7,47\% - 9,03\% dibandingkan dengan pakan yang tanpa penambahan probiotik. Selain itu peningkatan nutrisi juga terjadi pada pakan dengan probiotik yang ditandai melalui peningkatan kandungan protein, lemak dan kadar abu.

Peningkatan kualitas pakan juga dapat dilakukan dengan penambahan ekstrak dari bahan tertentu yang mampu memperbaiki kualitas kesehatan udang. Penelitian yang dilakukan Ridlo dan Pramesti (2009) menunjukkan efektifitas ekstrak rumput laut bagi sistem pertahanan non spesifik pada udang vanamei. Pemberian ekstrak rumput laut Sargasum sp. terbukti mampu meningkatkan total hemosit hingga $1,127 \times 10^{7} \mathrm{sel} /$ $\mathrm{L} \pm$ 0,260 dibandingkan dengan kontrol dengan total hemosit $0,541 \times 10^{7} \mathrm{sel} / \mathrm{L} \pm 0,160$. Pemberian rumput laut pada pakan mampu menstimulasi peningkatan total hemosit yang memegang peranan penting dalam sistem pertahanan non spesifik udang.

Bahan lain yang mampu meningkatkan kualitas pakan adalah karagenan. Polisakarida yang dihasilkan dari ekstrak alga merah ini digunakan sebagai bahan tambahan untuk memperbaiki tekstur pakan. Selain fungsinya ini karegenan dari rumput laut Kappapycus alvarezii juga memiliki dampak pada peningkatan sistem imun udang yang ditandai dengan peningkatan aktivitas fagosit pada udang yang telah diinfeksi IMNV (Infectious Myonecrosis Virus). Pemberian k-karagenan selama 14 hari secara berulang dengan interval pemberian tujuh hari (minggu pertama dan keempat) dan dosis $15 \mathrm{~g} / \mathrm{kg}$ pakan menunjukkan

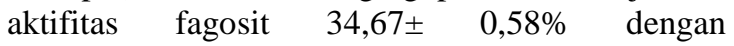
kelangsungan hidup 90\% (Febriani, dkk., 2013).

\subsection{Sistem pertahanan tubuh pada udang}

Sistem pertahanan tubuh pada udang berbeda dengan pada hewan darat ataupun pada manusia, yang lain mempunyai antibodi spesifik atau komplemen (Kwang 1996). Sistem pertahanan tubuh pada udang masih tergolong primitif dan tidak mempunyai sel memori, sehingga tidak mempunyai immunoglobulin yang berperan dalam mekanisme kekebalan tubuh (Sŏderhall, et al., 1998 dalam Mahasri, 2007). Selanjutnya oleh Roitt, et al., (1998) mengatakan bahwa sistem pertahanan tubuh pada hewan invertebrata melibatkan sel hemosit yang berperan dalam (1) fagositosis, (2) proses koagulasi dan pelepasan prophenoloksidase, (3) sintesis $\alpha_{2}$ macroglobulin, aglutinin dan antibacterial peptide dan (4) haemogram, yang meliputi Total Haemocyte Count (THC) dan Differential Haemocyte Count (DHC) yang terdiri dari Large Granular Haemocyte (LGH), Semigranular Haemocyte (SGH) dan Agranular Haemocyte Count (AHC). Sistem pertahanan tubuh pada udang windu merupakan sistem pertahanan tubuh alami (innate immunity) dan dianggap sama dengan invertebrata yaitu sistem pertahanan tubuh non spesifik karena hanya memiliki kekebalan alami (Van de Braak, 2002)

Secara umum sistem pertahanan tubuh udang terdiri dari dua bagian yaitu sistem pertahanan tubuh seluler dan sistem pertahanan tubuh humoral. Sistem pertahanan tubuh seluler meliputi fagosit sel-sel hemosit, nodulasi dan encapsulasi. Sistem pertahanan tubuh humoral mencakup phenoloksidase (PO), prophenoloksidase (proPO), lectin dan aglutinin. Sistem pertahanan seluler dan humoral yang penting pada udang tergantung dari faktor-faktor yang berperan pada sistem tersebut sebagai pertahanan tubuh melawan serangan organisme patogen. Salah satu faktor tersebut adalah lingkungan yang buruk akibat tingginya polusi oleh bahan organik. Polusi ini akan menghambat aktifitas fagosit dari udang yaitu lebih rendah daripada udang yang sehat (Itami, 1994).

Meningkatnya ketahanan tubuh dapat diketahui dari meningkatnya aktifitas sel-sel fagosit dari hemosit. Sel-sel fagositik ini berfungsi untuk melakukan fagositosis terhadap benda asing yang masuk ke dalam tubuh inang. Fagositosis merupakan mekanisme pertahanan non-spesifik yang secara umum mampu melindungi adanya serangan penyakit. Hemosit dikenal sebagai faktor yang sangat penting dalam sistem pertahanan seluler yang bersifat non-spesifik. Untuk mengetahui bahwa hemosit merupakan pertahanan tubuh yang bersifat seluler, dapat dilihat dari kemampuannya dalam aktifitas fagositosis yang dapat meningkat pada kejadian infeksi. Dengan adanya infeksi akan merangsang sistem pertahanan 
non-spesifik seluler sehingga diharapkan dapat menangkal serangan penyakit. Terdapat tiga bentuk mekanisme aktifitas hemosit yang dapat teramati, yaitu (1) mekanisme penjeratan (enkapsulasi) terhadap suatu materi asing, (2) mekanisme fagositosis gabungan dari beberapa hemosit yang membentuk kumpulan lebih besar, dan (3) kumpulan dari banyak hemosit membentuk suatu lapisan terpigmentasi (Fontaine dan Lightner, 1974) dalam Mahasri (2007).

\subsection{Gambaran darah udang}

Haemolim atau darah udang terdiri dari plasma dan korpuskel (sel darah) dengan komponen organik dan anorganik. Komponen yang utama adalah natrium dan klorida, sedang yang sedikit adalah kalium, kalsium dan magnesium. Komponen organik terdiri dari gula, lemak dan protein. Darah udang tidak mengandung hemoglobin, sehingga darahnya tidak berwarna merah. Hemoglobin yang berfungsi untuk transpor oksigen, pada udang fungsi tersebut digantikan oleh hemosianin, suatu protein yang mengandung $\mathrm{Cu}$ dan bisa berikatan dengan oksigen. Hemosianin berfungsi dalam transpor oksigen, sebagai buffer dalam darah crustacea dan berperan penting dalam osmotik darah (Maynard, 1960). Selanjutnya menurut Frandson (1986) eritrosit merupakan sel darah berukuran kecil, tidak memiliki sitoplasma dan berfungsi untuk transpor oksigen. Pada udang ditemukan sel darah seperti itu dengan ukuran 5,6 $\mu \mathrm{m}$. Sel darah tersebut mungkin berfungsi sebagai transpor oksigen (Supamattaya, et al., 1994).

Person, et al. (1987) menyatakan bahwa jumlah hemosit dalam darah arthropoda (termasuk udang) menentukan tingkat kekebalan tubuh udang terhadap serangan penyakit. Selanjutnya dikatakan pula bahwa penurunan total hemosit akan menyebabkan kerusakan pada inang yang ditandai dengan reaksi melanisasi oleh jamur Aphanomyses astact pada jaringan kutikula, penetrasi pada jaringan tubuh dan disusul kematian organism. Maynard (1960) menyatakan bahwa sel darah hemolim atau juga disebut korpuskel dapat disamakan dengan leukosit pada vertebrata yang terdiri dari granulosit dan hialosit. Sel hyalin mempunyai nukleus yang besar terletak ditengah dikelilingi oleh sitoplasma basophilic, yang pada sitoplasma tidak terlihat adanya retikulum endoplasmik serta ribosom dan juga tidak ditemukan badan golgi, granul hampir tidak ada atau terlihat sangat sedikit. Martin (1985) menyatakan bahwa bentuk hemosit penaeid dibedakan menjadi bentuk yang tidak bergranula (agranulocyte), granulanya sedikit (semigranulocyte) dan bergranula banyak (granulocyte).

Menurut Owens dan O’Neill (1997) persentase hyaline pada udang yang normal terdiri dari $60 \%$ sampai $93 \%$ dari total hemosit, sedangkan persentase granulosit berjumlah $17 \%$ sampai 40\%. Berdasarkan analisis Cell-Dyn 3000 analisis total hemosit rata-rata berjumlah $2,1 \times 10^{7}$. Granulosit merupakan jaringan untuk sistem pertahanan seluler melawan infeksi, sel ini akan bermigrasi ke daerah-daerah yang mengalami infeksi. Gambaran proses degranulasi hemosit disajikan pada Gambar 2.2

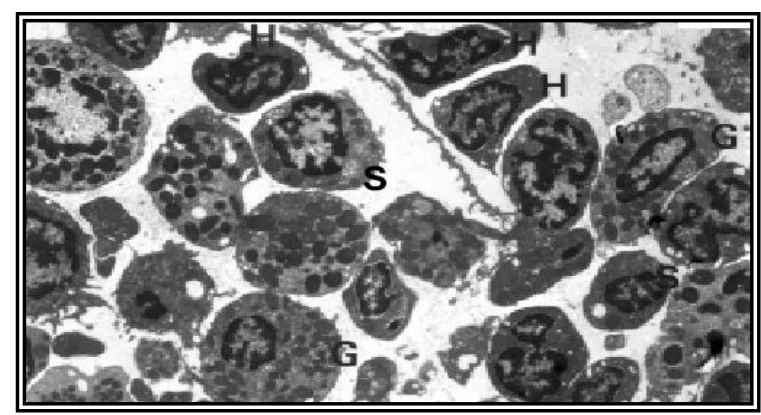

Gambar 2.2. Jenis Sel Hemosit Udang Windu (Penaeus monodon Fab.) Keterangan : $\mathrm{Gr}=$ Sel granular; Hy = Hyalin; $\mathrm{S}=$ Semi Granular (Sumber : Van de Braak, 2002). Perbesaran 1500x

Granulosit mengandung granula di dalam sitoplasmanya, dan memberi warna biru dengan pewarnaan giemza (Supamattaya, et al, 1994). Gani (1995) menyatakan bahwa persentase granulosit pada udang windu yang terserang Yellow Head Disease (YHD) memiliki jumlah granulosit 53 - 60\%, dibanding dengan kontrol $26-44 \%$. Johanson dan Sŏderhall (1989) mengatakan bahwa sel hyalin juga berperan di dalam sistem pertahanan tubuh udang. Sel hyalin ini diaktifkan oleh Opsonin Factor yang dihasilkan dari aktifnya proPO menjadi PO pada sel granular, sehingga dapat memfagositosis materi asing baik bakteri maupun virus, tetapi yang paling berperan dalam sistem pertahanan tubuh udang adalah granulosit.

\subsection{Imunostimulan pada udang}

Imunisasi pada udang sudah mulai dikembangkan beberapa tahun terakhir (5-6 tahun yang lalu), akan tetapi sampai sekarang masih banyak para pakar yang meragukan keberhasilanya. Imunostimulan yaitu suatu bahan kimia yang dapat mengaktifkan sel darah putih (leukosit), sehingga organisme lebih tahan terhadap infeksi virus, bakteri, jamur dan parasit ( Raa, 2000). Imunisasi 
adalah memasukkan bahan kimia yang dapat mengaktifkan sel darah putih (leukosit) sehingga organisme lebih tahan terhadap infeksi virus, bakteri, jamur dan parasit. Di dalam tubuh udang, vaksin akan merangsang hemosit untuk melakukan degranulasi dan protein akan dilepaskan seperti ikatan molekul.

Imunisasi pada udang adalah suatu usaha untuk meningkatkan ketahanan tubuh udang dengan jalan memasukkan antigen ke dalam tubuh, dan selanjutnya juga dikenal dengan vaksinasi (Anderson, 1995). Vaksin merupakan produk yang dihasilkan dari suspensi mikroorganisme hidup maupun mati yang dapat menghasilkan kekebalan (Ellis, 1988). Itami et al. (1996) mengatakan bahwa pemberian vaksin (vaksinasi) dapat mencegah infeksi penyakit, karena bisa meningkatkan aktifitas fagosit hemosit dan proPO. Di samping itu vaksinasi juga dapat meningkatkan jumlah granulosit. Taslihan (1991) mengatakan bahwa terdapat penyebaran hemosit pada hepatopankreas pasca larva udang windu setelah dilakukan imunisasi. Penyebaran hemosit ini dapat diasumsikan sebagai bentuk dari mekanisme respon seluler terhadap masuknya benda asing ke dalam tubuh udang.

Imunostimulan yang masuk ke dalam tubuh udang windu akan merangsang hemosit untuk melakukan degranulasi dan akan melepaskan protein seperti binding molecule ( $\beta$ Glucan-binding protein / $\beta G-B P$, Lipopolysaccaride-binding protein /LPS-BP, Peptidoglycan-binding protein / $P G-B P)$ coagulation factors (transglutaminase), prophenoloxcide related factors (prophenoloxide activating enzyme, prophenoloxide, peroxinectin), protein inhibitors ( $\alpha_{2}$ macroglobulin) dan anti microbial substances (penaedin, lectin). Beberapa protein yang dilepas ini akan digunakan untuk kepentingan respon imun seperti : phagocytosis, encapsulation, melanization, coagulation, aktivitas enzim prophenoxidase, opsonisasi, aktivasi anti mikroba serta proses aktivitas humoral dan seluler lain ( Soderhall et al., 1998 ; Van de Braak et al. 2002).

Johanson dan Soderhall (1989) menyatakan bahwa imunisasi dapat merangsang hemosit untuk melepaskan sistem proPO (sistem komunikasi) dan protein probinding TGKpa (molekul sinyal) yang bertanggungjawab sebagai komunikator dan aktifator sel-sel untuk melakukan fagositosis dan enkapsulasi pada jenis crustasea.

Pemberian imunostimulan pada crustasea disebut juga vaksinasi tidak mempunyai efek samping dan sangat baik untuk diterapkan pada organisme yang tidak mempunyai sel memori dalam sistem imunnya, sehingga dapat merangsang dan atau memaksimalkan respon imun non spesifik (Kwang, 1996). Vaksinasi dengan menggunakan bahan protein antigenik (imunogenik) masih belum banyak dilakukan. Menurut Rukyani (1998) pemberian Lipopolisakarida (LPS) dari dinding sel bakteri Vibrio harveyi secara oral pada udang windu (Penaeus monodon Fab.) dalam waktu 42 hari dapat meningkatkan total hemosit dan menaikkan jenis sel granulositnya, sedangkan aktifitas fagositik dari sel hemosit sudah menunjukkan kenaikan pada hari ke 28 dan lebih tinggi lagi pada hari ke 42 . Terjadinya peningkatan aktifitas fagositik dari sel-sel hemosit seiring dengan meningkatnya total hemosit dan jenis sel granulositnya akibat pemberian Lipopolisakarida.

Brunk (1999) merekomendasi bahwa protein membran Tetrahymena yang merupakan satu famili dengan Ichthyophthirius multifiliis dapat dikembangkan sebagai bahan vaksin sub unit terhadap white spot (penyakit bintik putih) pada ikan. Selanjutnya Leff, et al. (1994) dalam hasil penelitiannya dinyatakan bahwa ikan Channel Catfish (Ictalurus punctatus) termasuk dalam ikan Cyprinidae yang diinfestasi dengan Ichthyophthirius multifiliis stadia theront dengan dosis 5.000 dan 10.000 sel/ekor menunjukkan adanya perbedaan infestasi pada insang dan kulit mulai hari ke 14 pasca infeksi. Selanjutnya dikatakan oleh Clark, et al. (1996) bahwa ikan Channel Catfish yang diimunisasi protein membran dari theront serotype G3 dan G4 dapat menekan infestasi Ichthyophthirius multifiliis dari 78,9\% menjadi 14,2\% selama 24 jam pemeliharaan.

Lin, et al. (1996) melanjutkan penelitiannya bahwa telah menemukan protein membran antigen dari theront serotype G1 terdiri dari protein dengan berat molekul $48 \mathrm{kDa}$ dan 60 $\mathrm{kDa}$, sedangkan serotype G3 hanya terdapat satu jenis protein membran yaitu dengan berat molekul $55 \mathrm{kDa}$. Selanjutnya protein membran antigen tersebut diimunisasikan pada ikan Channel Catfish dengan dosis $2 \mu \mathrm{g}$ dan diinfeksi dengan 5.000 theront menunjukkan bahwa 138 survive dari 140 ekor.

Wang dan Dickerson (2002) menemukan protein membran antigen dengan menggunakan SDS-PAGE dan immunoblotting dengan Western blotting dari stadia theront Ichthyophthirius multifiliis berada pada berat molekul $10-70 \mathrm{kDa}$. Kemudian penelitian ini dilanjutkan dan terbukti menemukan protein membran antigen dengan berat molekul 55 dan $46 \mathrm{kDa}$. Selanjutnya protein membran antigen ini digunakan untuk imunisasi pada ikan Channel Catfish dengan dosis $10 \mu \mathrm{g} / \mathrm{ikan}$ yang disuntikkan dengan cara intra peritoneal dan ditantang dengan 15.000 sel/ikan. Hasil imunisasi 
menunjukkan bahwa sampai pada hari ke 84 ikan masih survive $27 \%$, sedang pada kelompok kontrol semua sudah mati pada hari ke 14 .

\section{METODE PENELITIAN}

\subsection{Rancangan penelitian}

Penelitian ini menggunakan metode eksperimental laboratorik yang dirancang secara acak lengkap untuk mengetahui pengaruh pemberian pakan berimunostimulan terhadap laju pertumbuhan dan kelulushidupan udang. Kelulushidupan dilakukan dengan mengamati udang yang mati setiap hari hingga 30 hari, sedangkan laju pertumbuhan dilakukan dengan penimbangan dalam keadaan basah diawal dan diakhir penelitian. Adanya peningkatan respon imun dihitung dari peningkatan Total Haemocyte Count (THC) dan Differential Haemocyte Count (DHC). Rancangan penelitian yang digunakan adalah Rancangan Acak Lengkap (RAL) dengan 4 perlakuan dan 5 kali ulangan, yaitu : A : Kelompok Udang tanpa diberi pakan buatan tanpa diberi imunostimulan, B : Kelompok Udang yang diberi pakan buatan dan imunostimulan $8 \%, \mathrm{C}$ : Kelompok Udang yang diberi pakan buatan dan imunostimulan 10\%, D : Kelompok Udang yang diberi pakan buatan dan imunostimulan $12 \%, \mathrm{E}$ : Kelompok Udang yang diberi pakan buatan dan imunostimulan 14\%

\subsection{Tempat dan waktu penelitian}

Penelitian ini dilaksanakan pada bulan Maret sampai dengan Mei 2016. Pembuatan pakan untuk udang vaname dilakukan di Laboratorium Reproduksi Ternak, Fakultas Kedokteran Hewan Universitas Airlangga. Pengamatan kelulushidupan dan laju pertumbuhan serta respon imun (Pemeriksaan THC dan DHC) udang vanamei dilakukan di Laboratorium Basah Fakultas Perikanan dan Kelautan, Universitas Airlangga.

\subsection{Materi Penelitian}

\subsubsection{Bahan Penelitian}

Bahan yang digunakan dalam penelitian ini adalah udang vanamei sehat umur 40 hari di tambak (Juvenil) yang diambil dari tambak di Desa Kedung Pandan (Tlocor), Kecamatan Jabon, Kabupaten Sidoarjo. Pakan udang yang digunakan pada penelitian ini adalah pakan buatan hasil penelitian dengan nutrisi yang sesuai dengan kebutuhan udang. Imunostimulan yang digunakan adalah imunostimulan dari protein membran imunogenik Zoothamnium penaei yang sudah dilakukan uji proteksi secara laboratorik oleh
Mahasri (2007) dan Harijanto (2012), dan sudah diaplikasikan pada budidaya udang di tambak secara perendaman oleh Hendri (2013). Sedangkan bahan untuk pemeriksaaan dan penghitungan THC dan DHC adalah EDTA, methanol serta pewarna Giemsa.

\subsubsection{Peralatan Penelitian}

Peralatan untuk penelitian ini meliputi: 20 buah akuarium dengan volume 20 liter beserta perlengkapannya, mikroskop perbesaran 1000 kali. Untuk menghitung THC dan DHC diperlukan: staining jar, spuit $1 \mathrm{ml}$, mikroskop perbesaran 1000 kali dan hemositometer. Pengukuran survival rate dengan melakukan penghitungan langsung jumlah udang yang hidup dari awal hingga akhir penelitian. Pengukuran growth rate menggunakan timbangan digital. Pengukuran parameter kualitas air menggunakan peralatan antara lain : termometer, refkraktometer untuk mengukur salinitas, $\mathrm{pH}$ meter, DO-meter untuk mengukur kadar oksigen terlarut.

\subsection{Populasi, Besar dan Teknik Pengambilan Sampel \\ 3.4.1.Populasi dan Sampel}

Populasi dalam penelitian ini adalah populasi udang vanamei sehat umur 40 hari di tambak (stadia juvenile). Sampel dalam penelitian ini adalah udang vanamei sehat umur 40 hari dan darah udang vanamei.

\subsubsection{Besar Sampel dan Teknik Pengambilan Sampel}

Udang vanamei yang sehat umur 40 hari dengan berat 15-20 gram sebanyak 200 ekor. Sampel udang diambil secara acak dari populasi di tambak. Sampel dibawa ke laboratorium basah di Fakultas Perikanan dan Kelautan, dengan menggunakan kantong plastik yang diberi oksigen. Perlakukan pada penelitian terdiri dari 4 (empat) perlakuan dan 5 kali ulangan.

\subsection{Variabel Penelitian}

Variabel dari penelitian ini terdiri dari variabel bebas yang berupa persentase pakan dan dosis imunostimulan yang diberikan. Sedangkan variabel terikat meliputi : berat dan panjang udang, THC dan DHC. Untuk variabel kontrol meliputi udang vanamei umur 40 hari, berat 15-20 gram dan kualitas air.

\subsection{Pelaksanaan Penelitian}

3.6.1. Pembuatan Pakan Berimunostimulan 
Pakan buatan yang digunakan dalam penelitian ini adalah pakan hasil produksi Laboratorium Produksi Ternak Fakultas Kedokteran Hewan, Universitas Airlangga. Komposisi pakan yang digunakan dalam penelitian ini disajikan pada Tabel 4.1.

Tabel 4.1. Hasil Analisis Proksimat Pakan Buatan Yang Digunakan Dalam

\begin{tabular}{|l|l|l|l|}
\hline \multicolumn{1}{|c|}{ Penelitian } \\
& $\begin{array}{l}\text { Parameter } \\
\text { Uji }\end{array}$ & $\begin{array}{l}\text { Hasil } \\
\text { Uji }(\%)\end{array}$ & $\begin{array}{l}\text { Kebutuahn Nutrisi } \\
\text { Untuk Udang }(\%) \\
\text { (Ryna and } \\
\text { Medina (2011). }\end{array}$ \\
\hline 1. & $\begin{array}{l}\text { Protein } \\
\text { Kasar }\end{array}$ & $\begin{array}{l}30.202 \\
2\end{array}$ & 37.51 \\
\hline 2. & $\begin{array}{l}\text { Lemak } \\
\text { Kasar }\end{array}$ & 8.6010 & 13.11 \\
\hline 3. & $\begin{array}{l}\text { Serat } \\
\text { Kasar }\end{array}$ & 7.4144 & 2.32 \\
\hline 4. & $\begin{array}{l}\text { Berat } \\
\text { Kering }\end{array}$ & $\begin{array}{l}89.087 \\
9\end{array}$ & - \\
\hline 5. & Kadar Abu & 9.0944 & 12.40 \\
\hline 6. & Ca & 2.6692 & - \\
\hline 7. & BETN & 33.776 & 15.46 \\
\hline 8. & ME & $\begin{array}{l}2885.8 \\
592\end{array}$ & - \\
\hline 9. & Kadar Air & - & 9.71 \\
\hline
\end{tabular}

Imunostimulan yang digunakan dalam penelitian ini dibuat dari protein membran imunogenik dari Zoothamnium penaei yang dicampurkan pada pakan dengan dosis $8 \%, 10 \%$, $12 \%$ dan $14 \%$ dalam $1 \mathrm{~kg}$ pakan, yang dicampurkan dengan menyemprotkan dalam pakan buatan sebelum pakan diberikan. Pakan dikeringanginkan pada temperatur ruangan, kemudian pakan disimpan dalam lemari pendingin dan siap digunakan.

\subsubsection{Penentuan Kelulushidupan}

Berdasarkan penelitian yang dilakukan Nuhman (2009) pengamatan mengenai kelangsungan hidup dilakukan melalui pengamatan langsung dengan mengamati udang yang hidup saat awal hingga akhir penelitian. Rumus yang digunakan untuk mengukur menurut Effendi (1979) adalah:

$$
\mathrm{SR}=\frac{N t}{N o} \times 100 \%
$$

Keterangan: SR = Survival rate / Kelangsungan hidup (\%), $\mathrm{Nt}=$ Jumlah udang hidup pada akhir penelitian dan No = Jumlah udang hidup pada awal penelitian

\subsubsection{Penentuan Laju Pertumbuhan}

Pengamatan mengenai laju pertumbuhan dilakukan dengan menimbang udang dalam keadaaan basah dengan menggunakan timbangan digital pada awal penelitian dan akhir penelitian dengan menganalisa hasilnya menggunakan rumus:

$$
\mathrm{GR}=\frac{W t-W o}{t}
$$

Keterangan: GR = Growth rate (laju pertumbuhan $\mathrm{t}=$ lama pengamatan, $\mathrm{Wt}=$ berat akhir udang dan $\mathrm{Wo}=$ berat awal udang

\subsubsection{Penghitungan THC}

Hemolimfe udang diambil pada bagian pangkal pleopod pada segmen abdominal dekat lubang genital dengan menggunakan syringe $1 \mathrm{ml}$ yang telah dibasahi larutan antikoagulan (EDTA 10\%). Selanjutnya penghitungan THC dilakukan dengan hemositometer (Ridlo, 2009) dan dihitung dengan rumus :

$$
\text { Jumlah hemosit }=\frac{\text { Jumlah sel dihitung }}{\begin{array}{c}
\text { Volume dihitung } \\
\text { pengenceran } \times 10^{6}
\end{array}} \times
$$

\subsubsection{Penghitungan DHC}

Penghitungan DHC dilakukan dengan mengambil hemolimfe dari udang. Hemolimfe diteteskan pada gelas objek dan dibuat ulasan, lalu dikering aginkan dan difikasi dengan methanol $100 \%$ selama 5 menit. Kemudian diwarnai dengan larutan Giemsa $10 \%$ dan didiamkan selama 10 menit, setelah itu dicuci dengan air mengalir selama 30 detik dan dikeringanginkan kembali. Preparat yang sudah jadi diamati menggunakan mikroskop perbesaran 100 kali dan dibedakan menurut jenis selnya (Pebrianto, dkk. 2010). Penghitungan DHC dilakukan dengan mengelompokkan sel hemosit dalam 3 tipe sel yaitu sel granular, semi granular dan hialin di bawah mikroskop dengan perbesaran 400 kali. Tipe sel hemosit yang dihitung berjumlah 100 sel lalu presentase tiap jenis sel dihitung dengan rumus (Tampangallo, dkk. 2012):

Presentase jenis sel hemosit $=$

Jumlah sel hemosit tertentu Total sel hemosit

\subsection{Pengumpulan dan Analisis Data}

Data kelulushidupan, laju pertumbuhan dan Total Haemocyte Count (THC) serta Total Differential Count (DHC) pada udang dianalisis dengan 
ANOVA, dan bila terdapat perbedaan antar perlakukan dilanjutkan dengan Uji Jarak Berganda Duncan (Steel and Torrie, 1992).

\section{HASIL DAN PEMBAHASAN 4.1. Hasil Penelitian}

\subsubsection{Laju Pertumbuhan Udang Vaname}

Hasil penghitungan menunjukkan bahwa laju pertumbuhan udang vaname dapat dilihat pada Lampiran 1, sedangkan analisis statistik secara lengkap dapat dilihat pada Lampiran 2. Rata-rata nilai laju pertumbuhan udang pada perlakuan A, B, C, D dan E berturut-turut adalah sebesar 0,0229 $\pm 0,0202,0,0212 \pm 0,0215$, $0,0108 \pm 0,0050,0,0150 \pm 0,0043$ dan $0,0075 \pm 0,0032$ (Tabel 5.1). Kelaompok A merupakan Kelompok udang vaname tanpa diberi pakan buatan tanpa diberi imunostimulan, B : Kelompok udang vaname yang diberi pakan buatan dan imunostimulan 8\%, C : Kelompok udang vaname yang diberi pakan buatan dan imunostimulan 10\%, D : Kelompok udang vaname yang diberi pakan buatan dan imunostimulan $12 \%$ dan E adalah Kelompok udang vaname yang diberi pakan buatan dan imunostimulan $14 \%$

Berdasarkan analisis statistik terhadap laju pertumbuhan (y w/t)dengan uji $\mathrm{F}$ (Anava) didapatkan nilai signifikansi sebesar 0,337 yang berarti tidak terdapat perbedaan signifikan ( $p$ > $0,05)$, demikian juga uji Duncan 5\% tidak terdapat perbedaan signifikan $(p>0,05)$ antar perlakuan.

Tabel 4.1 Rata-rata Laju Pertumbuhan Udang pada Berbagai Perlakuan

\begin{tabular}{|c|c|c|}
\hline \multirow[b]{2}{*}{ Perlakuar } & \multicolumn{2}{|c|}{ Mean \pm Std. Deviation } \\
\hline & $\begin{array}{c}\text { Laju pertumbuhan } \\
(\mathrm{y} \mathrm{w/t})\end{array}$ & $\begin{array}{c}\text { Transformasi ke } \\
\sqrt{ }(\mathrm{y} \%)\end{array}$ \\
\hline A & $0,0229^{\mathrm{a}} \pm 0,0202$ & $0,1425 \pm 0,059$ \\
\hline $\mathrm{B}$ & $0,0212^{a} \pm 0,0215$ & $0,1343 \pm 0,065$ \\
\hline $\mathrm{C}$ & $0,0108^{\mathrm{a}} \pm 0,0050$ & $0,1021 \pm 0,024$ \\
\hline $\mathrm{D}$ & $0,0150^{\mathrm{a}} \pm 0,0043$ & $0,1215 \pm 0,018$ \\
\hline E & $0,0075^{\mathrm{a}} \pm 0,0032$ & $0,0848 \pm 0,020$ \\
\hline
\end{tabular}

Superskrip yang sama pada kolom yang sama menunjukkan tidak ada perbedaan yang nyata antar perlakuan $(\mathrm{p}>0,05)$

\subsubsection{Hasil PenghitunganTHC (10 jt sel/mL) pada Udang Vaname}

Hasil penghitungan THC dapat dilihat pada Lampiran 1, sedangkan analisis statistik secara lengkap dapat dilihat pada Lampiran 3. Rata-rata nilai THC dari perlakuan A hingga E secara berurutan adalah 51,4975, 53,7525, 59,3000, 55,3250 dan $57,1575 \times 10^{3} \mathrm{sel} / \mathrm{ml}$. Secara lengkap nilai tersebut dapat dilihat pada Tabel 5.2 menunjukkan bahwa THC yang paling rendah terjadi pada perlakuan A dan paling tinggi terjadi pada perlakuan E. Berdasarkan analisis statistik dengan uji $\mathrm{F}$ (Anava) terhadap nilai THC didapatkan signifikansi sebesar 0,000 , hal ini berarti terdapat perbedaan sangat signifikan ( $\mathrm{p}<$ 0,01 ). Setelah dilakukan uji Duncan 5\% dapat deketahui bahwa nilai THC tertinggi didapatkan pada $\mathrm{C}$ yang menunjukkan perbedaan signifikan ( $\mathrm{p}$ $<0,05$ ) dengan perlakuan lain, sedangkan THC terendah didapatkan pada perlakuan A yang juga menunjukkan perbedaan signifikan $(\mathrm{p}<0,05)$ dengan perlakuan lain.

Tabel 4.2 Rata-rata THC Udang pada Berbagai Perlakuan

\begin{tabular}{|c|c|}
\hline Perlakuan & Mean \pm Std. Deviation \\
\hline A & $51,4975^{\mathrm{a}} \pm 0,5035$ \\
\hline B & $53,7525^{\mathrm{b}} \pm 0,3669$ \\
\hline C & $59,3000^{\mathrm{d}} \pm 0,4955$ \\
\hline D & $55,3250^{\mathrm{b}} \pm 2.5422$ \\
\hline E & $57,1575^{\mathrm{c}} \pm 0,2634$ \\
\hline
\end{tabular}

${ }^{\mathrm{a}-\mathrm{d}}$ Superskrip berbeda pada kolom sama, menunjukkan perbedaan signifikan $(\mathrm{p}<0,05)$

\subsubsection{Hasil Penghitungan DHC (y \%)}

Hasil penghitungan DHCdapat dilihat pada Lampiran 1, sedangkan analisis statistik secara lengkap dapat dilihat pada Lampiran 4. Rata-rata nilai DHC dari perlakuan A hingga E secara berurutan adalah $12,8350 \pm 0,5213,11,9225$ $\pm 0,2925,14,4875 \pm 0,4615,12,8225 \pm 0,7728$ dan $13,0100 \pm 0,4801$, secara lengkap nilai tersebut dapat dilihat pada Tabel 5.2.

Tabel 4.3 Rata-rata Nilai DHC Udang pada Berbagai Perlakuan

\begin{tabular}{|c|c|c|}
\hline \multirow{2}{*}{ Perlakuan } & \multicolumn{2}{|c|}{ Mean \pm Std. Deviation } \\
\cline { 2 - 3 } & DHC $(\%)$ & $\begin{array}{c}\text { Transformasi ke } \\
\sqrt{ }(\mathrm{y} \%)\end{array}$ \\
\hline $\mathrm{A}$ & $12,8350^{\mathrm{b}} \pm 0,5213$ & $3,5820 \pm 0,0731$ \\
\hline
\end{tabular}




\begin{tabular}{|c|c|c|}
\hline B & $11,9225^{\mathrm{a}} \pm 0,2925$ & $3,4527 \pm 0,0422$ \\
\hline C & $14,4875^{\mathrm{c}} \pm 0,4615$ & $3,8059 \pm 0,0608$ \\
\hline $\mathrm{D}$ & $12,8225^{\mathrm{b}} \pm 0,7728$ & $3,5796 \pm 0,1091$ \\
\hline $\mathrm{E}$ & $13,0100^{\mathrm{b}} \pm 0,4801$ & $3,6065 \pm 0,0668$ \\
\hline
\end{tabular}

${ }^{a-c}$ Superskrip berbeda pada kolom sama, menunjukkan perbedaan signifikan $(\mathrm{p}<0,05)$

Berdasarkan analisis statistik dengan uji $\mathrm{F}$ (Anava) terhadap nilai DHC didapatkan signifikansi sebesar 0,000 , hal ini berarti terdapat perbedaan sangat signifikan $(\mathrm{p}<0,01)$. Setelah dilakukan uji Duncan 5\% dapat deketahui bahwa nilai DHC tertinggi didapatkan pada $\mathrm{C}$ yang menunjukkan perbedaan signifikan $(\mathrm{p}<0,05)$ dengan perlakuan lain, sedangkan DHC terendah didapatkan pada $\mathrm{PB}$ yang juga menunjukkan perbedaan signifikan $(\mathrm{p}<0,05)$ dengan perlakuan lain. Diketahui pula bahwa nilai DHC pada perlakuan A, B dan $\mathrm{E}$ tidak menunjukkan perbedaan signifikan $(p>0,05)$.

\subsubsection{Hasil Penghitungan Survival Rate (SR) Udang Vaname}

Hasil penghitungan SR udang dapat dilihat pada Lampiran 1, sedangkan analisis statistik secara lengkap dapat dilihat pada Lampiran 5. Rata-rata nilai SR udang pada perlakuan A, B, C, D dan E berturut-turut adalah sebesar 48,75 \pm 4,787, 37,50 $\pm 2,887,76,25 \pm$ $2,500,57,50 \pm 2,887$ dan $62,50^{\mathrm{b}} \pm 2,887$ (Tabel $5.4)$.

Berdasarkan analisis statistik terhadap SR dengan uji $\mathrm{F}$ (Anava) didapatkan nilai signifikansi sebesar 0,000 yang berarti terdapat perbedaan sangat signifikan $(\mathrm{p}<0,01)$.Setelah dilakukan uji Duncan 5\% dapat diketahui bahwa nilai SR teringgi didapatkan pada PC yang menunjukkan perbedaan signifikan $(p<0,05)$ dengan perlakuan lain, sedangkan nilai SR terendah didapatkan pada perlakuan A yang menunjukkan perbedaan signifikan $(\mathrm{p}<0,05)$ dengan perlakuan lain.Diketahui pula bahwa nilai SR pada perlakuan $\mathrm{B}$, D dan $\mathrm{E}$ tidak menunjukkan perbedaan signifikan $(\mathrm{p}>0,05)$.

Tabel 4.4 Rata-rata SR Udang pada Berbagai Perlakuan

\begin{tabular}{|c|c|}
\hline Perlakuan & Mean \pm Std. Deviation \\
\hline A & $48,75^{\mathrm{a}} \pm 4,787$ \\
\hline B & $37,50^{\mathrm{b}} \pm 2,887$ \\
\hline C & $76,25^{\mathrm{c}} \pm 2,500$ \\
\hline D & $57,50^{\mathrm{b}} \pm 2,887$ \\
\hline
\end{tabular}

\author{
$\mathrm{E}$ \\ $62,50^{\mathrm{b}} \pm 2,887$ \\ ${ }^{\mathrm{a}-\mathrm{c}}$ Superskrip berbeda pada kolom sama, \\ menunjukkan perbedaan signifikan \\ $(\mathrm{p}<0,05)$

\subsubsection{Hasil Pemeriksaan Kualitas Air Selama Pemeliharaan Udang}

Hasil pemeriksaan kualitas air terhadap parameter yang diperiksa ditujukan untuk digunakan sebagai data pendukung penelitian. Parameter kualitas air yang diperiksa meliput : Oksigen terlarut, Nitrit, Amoniak, Suhu, $\mathrm{pH}$ dan Salinitas. Hasil pemeriksaan secara lengkap disajikan pada Tabel 4.5 .

\subsection{Pembahasan \\ 4.2.1 Laju Pertumbuhan Udang}

Pakan yang digunakan dalam penelitian ini adalah pakan buatan dengan kandungan protein kasar $(30,20 \%)$, lemak kasar $(8,60 \%)$ dan serat kasar $(9,09 \%)$ pada pakan lebih rendah jika dibandingkan dengan kebutuhan protein untuk udang vaname berturut-turut, yaitu 37,51\%, $13,11 \%$ dan 12,40\% (Ryna and Medina, 2011). Hal ini menyebabkan tidak terdapatnya perbedaan antara laju pertumbuhan udang vaname yang diberi pakan buatan berimunostimulan dan tidak diberi imunostimulan dan sesudah dipelihara selama 30 hari. Rendahnya protein, lemak kasar dan serat kasar pada pakan buatan yang digunakan akan mempengaruhi pertumbuhan udang. Laju pertumbuhan udang pada semua perlakuan menunjukkan nilai yang rendah yaitu antara 0,022 $\%$ sampai dengan $0,010 \%$. Berdasarkan hasil analisis statistik, maka laju pertumbuhan udang vaname pada semua perlakuan $\mathrm{A}, \mathrm{B}, \mathrm{C}, \mathrm{D}$ dan $\mathrm{E}$ tidak memberikan pengaruh yang signifikan $(p>0,05)$. Hal ini tidak sesuai dengan pendapat Haliman dan Adijaya bahwa laju pertumbuhan udang vaname di pada umur 1 bulan di tambak berkisar antara $0,0911 \%$ hingga $0,1220 \%$, bahkan pada perlakuan A yang tidak diberi pakan buatan yang berimunostimulan nampak masih cenderung menunjukkan angka yang lebih tinggi dari laju pertumbuhan pada ke empat perlakuan lainnya. Rendahnya laju pertumbuhan udang vaname ini disebabkan karena nutrisi pakan yang diberikan masih terlalu rendah jika dibandingkan dengan kebutuhan nutrisi udang pada umumnya. Hal ini tidak sesuai dengan pendapat Heptarina, dkk. (2010) pakan dengan kadar protein yang lebih tinggi dari pakan yang diberikan yaitu 35\%, $15,20 \%$ lemak dan 5,31\% serat kasar menghasilkan pertumbuhan udang vaname dan konversi pakan 
terbaik. Rendahnya adar protein yang sesuai, kadar lemak yang tidak terlalu rendah menyebabkan udang mengkonsumsi pakan yang tidak cukup nutrisinya untuk pertumbuhannya. Pada perlakukan lain di mana kadar lemak mencapai $17,36 \%$, konsumsi pakan menjadi rendah sebab pada batas jumlah tertentu udang akan menghentikan aktivitas makannya akibat energi yang terlalu tingggi pada pakan dan nutrien pakan yang lain seperti protein akan kecil kemungkinannya untuk masuk ke tubuh udang sehingga laju pertumbuhan menjadi rendah.

\subsubsection{Gambaran THC Udang Vaname}

Peningkatan Total Haemocyte Count (THC) menunjukkan jumlah sel haemosit secara keseluruhan yang terdiri dari : sel haemosit agranular (hyaline), semi granular dan sel haemosit granular. Tabel 5.2 menunjukkan bahwa terjadi peningkatan total haemosit (THC) pada udang vaname setelah dipelihara selama 30 hari. Pada Tabel tersebut juga menunjukkan bahwa THC terendah ditemukan pada kelompok udang A yaitu udang yang tidak diberi pakan buatan berimunostimulan. Sedangkan THC tertinggi pada Perlakuan E yang juga berbeda nyata dengan perlakuan lainnya (Tabel 5.2). THC pada kelompok udang yang diberi pakan berimunostimulan sebanyak $8 \%$ (B) menunjukkan tidak berbeda nyata dengan kelompok udang yang diberi pakan buatan berimunostimulan sebanyak $12 \%$ (D) tetapi berbeda nyata dengan kelompok udang yang lainnya. Tidak berbeda THC pada kelompok udang B dan D kemungkinan disebabkan karena selama pemeliharaan terjadi infeksi oleh patogen pada kelompok tersebut. Dalam penelitian ini tidak diperiksa apakah udang terinfeksi patogen selama pemeliharaan. Adanya infeksi ini menyebabkan terjadinyanya peningkatan sel granular pada bagian udang yang terinfeksi patogen tersebut. Hal ini akan menyebabkan adanya perubahan THC pada udang (Van de Braak, 2002). Kemudian pendapat dari Anderson dan Siwicki (1995) yang menyatakan, bahwa apabila terjadi infeksi oleh patogen maka akan terjadi peningkatan total haemosit, karena meningkatnya total haemosit ini menunjukkan adanya fase infeksi. Pada saat terjadi infesksi sel darah akan bermigrasi ke daerah yang terinfeksi patogen tersebut. Hal ini menyebabkan pada saat pengambilan darah pada organ sirkulasi akan menyebabkan terdinya penurunan THC walaupun masih lebih tinggi dari pada udang kelompok D, tetapi secara statistik tidak terdapat perbedaan. Hal ini sesuai dengan pendapat dari Van de Braak (2002) yang mengatakan bahwa terjadi penurunan THC dan DHC pada sirkulasi darah udang bila terjadi infeksi patogen, karena sel haemosit bermigrasi ke daerah di sekitar infeksi.

\subsubsection{Gambaran DHC Udang Vaname}

Deferrent Haemocyte Count (DHC) juga merupakan indikator adanya respon imun pada udang, yaitu jumlah sel haemosit granular yang dinyatakan dalam persen. Tabel 5.3. menunjukkan bahwa DHC yang tertinggi terjadi pada kelompok udang pada perlakuan C yaitu 14,4875\% yang berbeda nyata dengan perlakuan $\mathrm{A}, \mathrm{B}, \mathrm{D}$ dan $\mathrm{E}$ dan DHC terrendah terjadi pada kelompok B yaitu $11,9225 \%$, sedangkan DHC pada kelompok udang $\mathrm{D}, \mathrm{E}$ dan A menunjukkan tidak ada perbedaan yang nyata, tetapi menunjukkan kecenderungan adanya peningkatan dari DHC pada kelompok udang tersebut, kecuali pada udang dari kelompok B. Terjadinya peningkatan yang nyata dari DHC (sel haemosit granular), disebabkan karena imunostimulan yang masuk ke dalam tubuh udang dapat menginduksi mekanisme pertahanan tubuh udang.

Mekanisme pertahanan tubuh pada udang tidak seperti pada ikan dan mamalia yang mempunyai imunoglobulin. Imunoglobulin pada udang digantikan oleh Prophenoloxidase Activating Enzim (PPA) (Soderhall dan Cerenius, 1992). PPA adalah protein yang berlokasi di sel granular hemosit. Dalam penelitian ini PPA tersebut diaktifkan oleh imunostimulan yang masuk ke dalam tubuh udang, yang akan merangsang prophenoloksidase menjadi phenoloksidase. Sebagai akibat dari perubahan ini akan dihasilkan semacam protein Opsonin Factor yang dapat menginduksi sel-sel hyalin untuk meningkatkan aktivitasnya (Johansson dan Soderhall, 1989).

Van de Braak (2002) dan Smith, et al. (2003) juga mendukung pernyataan diatas bahwa sel haemosit tersebut akan melakukan degranulasi, dan beberapa protein akan dilepas untuk kepentingan respon imun, seperti : meningkatnya sel haemosit, dan meningkatnya aktifitas penjeratan dan fagositosis. Di samping itu imunostimulan akan merangsang haemosit untuk melepaskan proPO dan protein-binding PPA, sehingga mengakibatkan sel haemosit meningkatkan aktifitasnya sebagai sel pertahanan tubuh.

\subsubsection{Tingkat Kelulushidupan (SR) Udang Vaname \\ Hasil penghitungan (Tabel 4.4) menunjukkan bahwa tingkat kelulushidupan udang vaname yang tertinggi $(76,25 \%)$ terjadi pada}


kelompok udang pada perlakuan $\mathrm{C}$ yaitu kelompok udang yang diberi pakan berimunostimulan dengan dosis $10 \%$, yang berbeda nyata $(\mathrm{p}<0,05)$ dengan kelompok udang pada perlakuan baik A, B, D maupun E. Tabel 5.4 juga menunjukkan bahwa tidak ada perbedaan yang nyata antara kelompok udang yang diberi pakan berimunostimulan yaitu kelompok B, D dan E, walaupun terdapat kecenderungan adanya peningkatan kelulushidupan seiring dengan meningkatnya dosis imunostimulan. Terdapatnya peningkatan tingkat kelulushidupan ini menunjukkan bahwa imunostimulan yang masuk ke dalam tubuh udang dapat melindungi (bersifat protektif) pada udang vaname terhadap adanya faktor luar yang masuk ke dalam tubuh udang, misalnya adanya infeksi oleh patogen yang merupakan salah satu penyebab utama terjadinya kematian udang. Hal ini disebabkan karena imunostimulan yang masuk ke dalam tubuh udang akan merangsang aktifitas selsel haemosit baik agranular (hyalin) maupun ganular, sebagai upaya untuk melawan patogen yang masuk dalam tubuh udang tersebut. Hal ini didukung oleh Mckay dan Jenkin (1970) dalam penelitiannya menunjukkan bahwa aktifitas fagositik pada crayfish (Parachaeraps bicarinatus) lebih aktif dilakukan oleh sel hyalin. Selanjutnya berdasarkan penelitian Paterson dan Keith (1992) bahwa aktifitas fagositosis haemosit pada American Lobster terhadap bakteri Aerococcus viridan Var. homari dilakukan oleh sel hyalin dan sel granular. Hasil penelitian Johanson dan Soderhall (1989), menunjukkan bahwa sel hemosit yang aktif memfagosit protozoa pada Callinectus sapidus adalah sel hyalin dan bakteri hanya di fagosit oleh sel granulosit. Fagositosis oleh sel hemosit udang lebih aktif dilakukan oleh sel hyalin dan sel semi granular.

Berdasarkan uraian di atas nampak bahwa penggunaan pakan berimunostimulan dengan dosis $10 \%$ memberikan berpengaruh yang terbaik terhadap respon imun dan kelulushidupan udang vaname. Khusus pengaruhnya terhadap laju pertumbuhan usdang, walaupun secara statistik tidak menunjukkan adanya pengaruh yang nyata, tetapi berat badan menunjukkan adanya kecenderungan ada peningkatan. Bila dikaitkan dengan kualitas air dengan parameter kunci yang diamati selama pemeliharaan yang selalu dalam keadaan yang normal, maka secara tidak langsung kualitas air ini juga ikut mendukung dan berperan dalam peningkatan respon imun, kelulushidupan dan laju pertumbuhan udang vaname.

\section{KESIMPULAN DAN SARAN}

\subsection{Kesimpulan}

1) Penggunaan imunostimulan dalam pakan buatan tidak dapat meningkatkan laju pertumbuhan (growth rate) pada udang vaname (Litopenaeus vannamei), sehingga tidak efektif diberikan pada udang vaname.

2) Penggunaan imunostimulan pada pakan buatan dapat meningkatkan respon imun (THC dan DHC) pada udang vaname (Litopenaeus vannamei), sehingga ketahanan tubuh udang vaname meningkat.

2) Penggunaan imunostimulan dalam pakan buatan dapat meningkatkan kelulushidupan (survival rate / SR) udang vaname (Litopenaeus vannamei).

3) Penggunaan imunostimulan dengan dosis $10 \%$ dalam pakan buatan merupakan dosis optimum dan efektif untuk meningkatkan respon imun dan kelulushidupan, akan tetapi untuk laju pertumbuhan udang vaname tidak menunjukkan adanya pengaruh yang nyata.

\subsection{Saran}

Saran yang dapat diajukan dari penelitian ini adalah perlu adanya penelitian lebih lanjut penggunaan imunostimulan dalam pakan buatan yang sesuai dengan kebutuhan udang vaname, karena pakan yang digunakan dalam penelitian ini mempunyai kandungan protein yang lebih rendah yaitu $37 \%$, padahal udang vaname membutuhkan pakan dengan kandungan protein $44 \%$.

\section{DAFTAR PUSTAKA}

Amrina, Wa Ode Rahmiathi, Wa Iba dan Abdul Rahman. 2013. Pemberian Silase Ikan Gabus pada Pakan Buatan Bagi Pertumbuhan dan Kelangsungan Hidup Udang Vaname (Litopenaeus vannamei) pada Stadia Larva Post Larva. Jurnal Mina Laut Indonesia. Kendari: Universitas Haluoleo.

Anderson, DP dan Siwicki. 1995. Basic Haemotology and Serology for Fish Health Programs. In Disease in Asian Aquaculture II. M. Shariff, J.R Arthur, R.P. Subangsinghe (Eds) Fish Health Section Asian Fisheries Society. p 185202.

Bokau, Rietje J.M, Wamiliana dan Sutikno. 2008. Pemodelan Program Linier untuk Optimasi Agroindustri Pakan Udang. Jurnal Sains MIPA, vol. 14 no.1 hal: 5964. 
Jurnal Biosains Pascasarjana Vol. 18 (2016) pp

(C) (2016) Sekolah Pascasarjana Universitas Airlangga, Indonesia

Briggs, M, Simon Funge Smith, Rohana Subangsinghe dan Michael phillips. 2004. Introduction and Movement of Penaeus vannamei and Pennaeus stylirostris in Asia and the Pasific. FAO. Bangkok.

Darmono. 1990. Budidaya Udang Penaeus. Penerbit Kanisius. Jakarta. 9-43.

Departemen Kelautan dan Perikanan. 2005. Revitalisasi Budidaya Udang di Indonesia. Makalah Disampaikan pada Pertemuan Teknis Petambak Udang se-Jawa Timur, Surabaya, 13 Februari.

Ellis, A.E. 1988. General Principles of Fish Vaccination. Academic Press. London. 19. Febriani, Dian, Sukenda dan Sri Nurhayati. 2013. Kappa-karagenan sebagai Imunostimulan untuk Pengendalian Penyakit Infectious myonecrosis (IMN) pada Udang Vaname Litopenaeus vannamei. Jurnal Akuakultur Indonesia 12(1),77-5.

Febrianto, C.A., Sukenda, Widanarni. 2010. Potensi Trichoderma sp. sebagai bahan antibakteral dan imunostimulan pada udang vaname (Litopenaeus vannamei). Jurnal Akuakultur Indonesia 9 (1), 1-8. Departemen Budidaya Perairan, Fakulatas Perikanan dan Ilmu Kelalutan, Institut Pertanian Bogor. Bogor, Indonesia.

Gustrifandi, H. 2013. Prevalensi Zoothamnium penaei, Respon Imun dan Kelulushidupan pada Udang Vaname (litopenaeus vannamei) di Tambak yang Diimunisasi dengan Protein Membran Imunogenik Zoothamnium penaei. Tesis, Program Pascasarjana, Universitas Airlangga.

Haemocytes. J. Morfology. 185: 339-384.

Haliman, RW dan D. Adijaya, S. 2005. Udang Vannamei. Penebar Swadaya. Jakarta.

Harijanto, 2012. Kemampuan Proteksi Imunostimulan dari Protein Membran Imunogenik Zoothamnium penaei Terhadap Zoothamniosis pada Udang Vannamei (Litopenaeus vannamei), Tesis, Program Pascasarjana, Universitas Airlangga.

Heptarina, Deisi, dkk. 2010. Pengaruh Pemberian Pakan dengan Kadar Protein Berbeda terhadap Pertumbuhan Yuwana Udang
Putih Litopenaeus vanamei. Prosiding Forum Inovasi Teknologi Akuakultur. Balai Riset Perikanan Budidaya Air Tawar. Bogor: Institut Pertanian Bogor.

Herawati, Vivi Endar. 2005. Mengembangkan Program Kuliah Mata Kuliah Manajemen Pemberian Pakan Ikan. Fakultas Perikanan dan Ilmu Kelautan. Semarang: Universitas Diponegoro.

Instalasi Pengolahan Air Limbah (IPAL). Jakarta Selatan.

Itami, T. 1994. Body Defence System of Penaeid Shrimp. Seminar on Fish Physiology and Prevention of Epizootic. Department of Aquaculture and Biology. Shimonoseki University of Fisheries. Japan. 7: 59-65.

Johanson, MW dan Sǒderhăll K. 1989. Cellular Imunity in Crustacean and pro System Parasitology Today. 5 (6): 171: 176.

Kordi, MGH. 1997. Budidaya Air Payau. Dahara Prize. Semarang.

Kwang, L.C. 1996. Immune Enhancer in the Control of Diseases in Aquaculture. Encap Technology Pte Ltd 14. Besut street. Jurong Town. Singapura. p.99-128.

Loy, John Dustin. 2011. Infection and Immunity in the Pasific white shrimp, Litopenaeus vannamei. Dissertation. Iowa State University. Ames, Iowa.

Mahasri, Gunanti. 2004. Efektifitas ikan Bandeng sebagai Filter Biologis Menekan Zoothamiosis pada Budidaya Udang Windu secara Intensif. Makalah Disampaikan pada Seminar Nasional Review Tentang Perkembangan Ilmu Pengetahuan dan Teknologi Perikanan, tanggal 30 November di Semarang.

Mahasri, Gunanti. 2007. Protein Membran Imunogenik Zoothamnium penaei Sebagai Bahan Pengembangan Imunostimulan pada Udang Windu (Panaeus monodon Fabricus) Terhadap Zoothamniosis. Disertasi. Surabaya: Universitas Airlangga.

Mahasri, Gunanti. 2013. Buku Ajar Manajemen Kualitas Air Fakultas Perikanan dan Kelautan Universitas Airlangga, Global Persada. Surabaya. 
Martin, G.G dan L.B Graves. 1990. Fine Stucture and Clasification of Shrimp

Muliani, Nurbaya dan Muharijadi Atmomarsono.2010. Penggunaan

Probiotik pada Pemeliharaan Udang Windu (Penaeus monodon) dengan Dosis Pakan yang Berbeda. Prosiding Forum Inovasi Teknologi Akuakultur 2010. Balai Riset Perikanan dan Budidaya Air Payau. Maros: Sulawesi Selatan.

Nuhman. 2008. Pengaruh Prosentase Pemberian Pakan terhadap Kelangsungan Hidup dan Laju Pertumbuhan Udang Vannamei (Litopenaeus vannamei). Jurnal Ilmiah Perikanan dan Kelautan Vol. 1 No. 2. Surabaya: Universitas Hang Tuah.

Owens, L dan O'Neill A. 1997. Use of Clinical Cell Flow Cytometry for Differential Counts of Prawn (Penaeus monodon) Haemocytes. Diseases of Aquatic Organisms. 31: 147-153.

Pamungkas, Wahyu, Ikhsan Khasani dan Raden Roro Sri Puji Sinarni Dewi. 2007. Pengaruh Vitamin C terhadap Perkembangan Gonad Induk Udang Galah (Macrobranchium rosenbergii). Jurnal Perikanan (J. Fish. Sci.) IX (2): 194-199 ISSN: 0853-6384. Subang: Loka Riset Pemuliaan dan Teknologi Budidaya Perikanan Air Tawar Sukamandi.

Panjaitan, Amyda Suryanti, Wartono hadie dan Sri Harijati. 2014. Pemeliharaan Larva Udang Vaname (Litopenaeus vannamei, Boone 1931) dengan Pemberian Jenis Fitoplankton yang Berbeda. Jurnal Manajemen Perikanan dan Kelautan vol. 1 no. 1. Jakarta: Universitas Terbuka.

Person, M, cerenius L dan Sǒderhăll K. 1987. The Influence of Haemocyte Number on The Resestance of The Freshwater Crayfish Pacifastacus leniusculus Dana, to the Parasitic fungus Aphanomyces astaci. Fish Disease J. 10: 471-477.

Raa J. 2000. The Use of Immunostimulant in Fish and Shellfish Feeds. In : LE. Cruz Suarez, D. Richie-Marie, M. Tapia - Salazar, MA. Olver - Novoa, R. Civera-Cerecedo, (Eds), Avences en Nutricion Acuicola. Merid,Yucatan, Mexico:47-54.
Reyna, C.E. Medina. 2001. Growth and Emigration of White Shrimp Litopenaeus vannamei, in the Mar Muerto Lagoon, Southern Mexico. Naga, The ICLARM Quarterly (Vol. 24, Nos 3\&4) JulyDecember 2001.

Riani, Hanisa, R. Rostika dan W. Lili. 2012. Efek Pengurangan Pakan terhadap Pertumbuhan Udang Vaname (Litopenaeus vannamei) PL-21 yang Diberi Bioflok. Jurnal Perikanan dan Kelautan vo. 3 no. 3. Universitas Padjajaran.

Ridlo, Ali dan Rini Pramesti. 2009. Aplikasi Ekstrak Rumput Laut sebagai Agen Imunostimulan Sistem Pertahanan Non Spesifik pada Udang (Litopenaeus vannamei). Ilmu Kelautan, Universitas Diponegoro. Semarang.

Roitt I, Brostoff J dan Male D. 1998. Immunologi 4th Ed. Barcelona. Spain. Mosby. Times Mirror International Publisher Limited.

Rukyani A. 1996. Jenis Penyakit Udang di Tambak dan Cara Pengendaliannya. Makalah Pertemuan Aplikasi Paket Teknologi Pertanian. Tanggal 9-11 Januari di BIP Lampung.

Subaidah, Siti, dkk. 2010. Perbaikan Nutrisi Induk Udang Vanname (Litopenaeus vannamei) dengan Kombinasi Pakan Segar dan Pakan Buatan.

Sugiono. 1997. Statistika untu Penelitian. Bandung: Alfabeta.

Sukarman dan L. Sholichah. 2011. Status Mineral dalam Pakan Ikan dan Udang. Prosiding Forum Inovasi Teknologi Akuakultur. Depok: Balai Riset Budidaya Ikan Hias.

Supamattaya, K., J. Kasornchandra dan S. Boonyaratpalin. 1994. Comparative Study of Simple Methods for the Diagnostic of Yellow Head Diseases in The Blach Tiger Shrimp (Penaeus monodon Fab.) Asean Shrimp News. 1st Quarter 1994. Thailand:43-56.

Suwoyo, Hidayat Suryanto dan Markus Mangampa. 2010. Aplikasi Probiotik dengan Konsentrasi Berbeda pada Pemeliharaan Udang Vaname (Litopenaeus vannamei). Prosiding Forum 
Jurnal Biosains Pascasarjana Vol. 18 (2016) pp

(C) (2016) Sekolah Pascasarjana Universitas Airlangga, Indonesia

Inovasi Teknologi Akuakultur. Sulawesi Selatan.

Tampangallo, Bunga R., Chalvyn Silasa Pakidi dan A. Rantetondok. 2012. Respon imun udang windu (Penaeus monodon) yang dipapar bakteri Vibrio harveyi. Prosiding InSINas.

Taslihan, A. 1991. Jenis Penyakit yang Menyerang Udang Windu. Makalah Disampaikan pada Workshop Penetapan Hama dan Penyakit Ikan Karantina Bogor 10-12 September. hal.7-17.

Tizard IR. 1988. Pengantar Imunologi Veteriner (Terjemahan). Airlangga University Press. Surabaya.

Tricahyo, E. 1995. Biologi dan kultur udang windu (Penaeus monodon Fabr.). Akademika Pressindo. Jakarta.

Van de Braak K. 2000. Haemocytic Defence in Black Tiger Shrimp (Penaeus monodon). Disertation. Van Wareningen Universiteit. Germany.

Widanarni, Dinamella Wahjuningrum dan Fiska Puspita. 2012. Aplikasi Bakteri Probiotik melalui Pakan Buatan untuk Meningkatkan Kinerja Pertumbuhan Udang Windu Penaeus monodon. Jurnal Sains Terapan Edisi II vol-2 (1). Bogor: IPB.

WWF Indonesia. 2014. Budidaya Udang Vannamei Tambak Semi Intensif dengan

Yustianti, Moh. Noh Ibrahim dan Ruslaini. 2013. Pertumbuhan dan Sintasan Larva Udang Vaname (Litopenaeus vannamei) Melalui Substitusi Tepung Ikan dengan Tepung Usus Ayam. Program Studi Budidaya Perairan FPIK Universitas Haluoleo Kampus Hijau Bumi Tridharma Kendari 93232 